\title{
MYBL2 Gene
}

National Cancer Institute

\section{Source}

National Cancer Institute. MYBL2 Gene. NCI Thesaurus. Code C18409.

This gene plays a regulatory role in cell cycle progression. 